\title{
The Legal Nature of Cooperative Membership
}

\section{ABSTRACT}

Membership is one of the core structural characteristics of the cooperative form. It distinguishes cooperatives from other business forms, especially companies. Cooperative membership is often regulated in national laws; however, the question of how membership should be translated into legal rules, has been largely unexplored. This is quite unfortunate, since to fully understand the complex relation between the cooperative and its members-and the mutual purpose of the cooperative-one must study the legal nature of cooperative membership. The purpose of this article is to investigate the legal dimensions of cooperative membership and how cooperatives differ from mainstream companies. The analysis is structured so that first the distinctive normative features of cooperative membership are assessed on a general level. Next, the focus shifts to the members' rights and obligations with the aim to provide a systematic overview regarding their justification and structure. Finally, the question of how cooperative membership should be regulated de lege ferenda, is briefly discussed. The findings of this article suggest that when translating membership into legal rules, special attention should be paid to the cooperative identity. It is particularly important to distinguish membership from shareholdership and to understand the central role of the members as user-owners of the enterprise. The purpose of the cooperative is based on member participation and without such interaction, cooperatives would ultimately lose their true identity. This article also points out several membership-related issues, which require further attention, and such studies are necessary to determine how cooperative law should be developed in the future.

\section{KEY-WORDS}

COOPERATIVE LAW; COOPERATIVE MEMBERSHIP; COMPARATIVE LAW; COMPANIZATION; COOPERATIVE SHARES 


\section{Introduction}

Cooperatives are person-centred mutual enterprises, aimed at promoting the aggregate welfare of their members as consumers, providers and/or workers. This objective distinguishes cooperatives from investor-centred companies focusing on shareholder value maximization ${ }^{1}$. Cooperatives are neither non-profit organizations (i.e., social enterprises), even though concern for community is one of the cornerstone principles of the international cooperative movement ${ }^{2}$. As Fici (2017b: 540) puts it, "[t]he mutual purpose, which characterizes co-operatives ... must be distinguished by both the for-profit and not-for-profit purpose, although it shares some traits of both". This means that a cooperative should be perceived as a cooperative (i.e., as a mutual enterprise), per se, not as a particular type of for-profit company or non-profit social enterprise ${ }^{3}$.

The legal relation between a company and its owners is anonymized by shares, hence owners of the enterprise are called shareholders. In company law theory the shareholder is typically perceived as a profit-seeking investor, a mere "provider of capital" (Ferran, 1999; Siems, 2008; Armour et al., 2017), whose rights and obligations towards the firm are not personal but bound to the share(s) he/she holds. Therefore, these instruments of indirect ownership are, in principle, freely transferrable and for the company the identity of its owners is — at least in theory_-irrelevant ${ }^{4}$. Then again, in the context of the cooperative, the relation between the enterprise and its owners is far more personal in nature. In fact, there is no instrument similar to the company's share to constitute the property rights of the cooperators. Therefore, the owners of a cooperative are called "members" and their rights and obligations towards the enterprise are derived from the membership, itself5. To fully understand this complex relation-and the mutual purpose of the cooperative-one must study the legal nature of cooperative membership.

\footnotetext{
See also Birchall (2011), who argues that this description fits all member-owned businesses (MBOs); hence, it might distinguish cooperatives from companies but not from other MBOs.
}

2 See the International Co-operative Alliance's (ICA) seventh Cooperative Principle: "Co-operatives work for the sustainable development of their communities through policies approved by their members".

3 See differently Hansmann (1996; 2013), who argues that ultimately all firms are cooperatives. In addition, it is important to note that many jurisdictions allow it to be stipulated in the cooperative's by-laws that the purpose of the cooperative is non-profit. Furthermore, a novel trend in cooperative law is the introduction of so-called social (or non-benefit or general interest) cooperatives. See, e.g., Argyrou and Lambooy (2017).

4 In fact, in many countries, such as in France and Spain, (public) companies limited by shares are called aptly "anonymous societies".

5 In older literature, Wolff (1907: 50) has aptly encapsulated the differences between the shareholders of a company and the members of a cooperative: "The joint stock company is a union of money units, each of which carries a vote. The co-operative society is a union of persons. These persons do not, like the shareholders in a joint stock bank, join together to earn a profit out of others. They combine not as dealers but as customers". In some countries, however, shareholders of a company are also called members. E.g., according to Section 112(2) of the UK's Companies Act 2006 “[e]very other person who agrees to become a member of a company, and whose name is entered in its register of members, is a member of the company". 
The purpose of this article is to examine how cooperative membership translates into legal rules and how it distinguishes cooperatives from mainstream companies. This question has not received sufficient scholarly attention to date, although different elements of cooperative membershipespecially the members' rights and obligations towards the society-have been introduced in the literature (Henrÿ, 2012; Münkner, 2016) ${ }^{6}$. There is a genuine need for a systematic analysis regarding this topic, as it helps us to: (i) understand the differences between cooperatives and companies; (ii) construct a theoretical framework for cooperatives; and (iii) determine how cooperative law should be developed. Furthermore, it must be noted that the legal essence of the cooperative membership is one of the "core structural characteristics" of the cooperative form, and there is no doubt that it should be preserved through law ${ }^{8}$. In fact, one can argue that by promoting cooperatives as membercentred service organizations, one simultaneously strengthens their true identity (ICA, 2015).

The following analysis is structured so that first the distinctive features of cooperative membership are introduced on a general level (Section 2). The main purpose of this investigation is to explain the legal status of a member in relation to the cooperative enterprise and to her/his fellow members, how member elections and exclusions are regulated, and how the membership of a cooperative differs from the shareholdership of a company. Next, the focus shifts to the members' rights and obligations and the objective is to provide a systematic overview regarding their justification and structure (Section 3). Finally, in Section 4, the question of how cooperative membership should be regulated de lege ferenda, is discussed in the form of concluding remarks.

\section{Distinctive features of cooperative membership: a legal perspective}

\subsection{Normative background}

The main international sources of cooperative law are the 1995 ICA's Statement on the Cooperative Identity (ICA Statement) ${ }^{9}$, the 2001 UN Guidelines on creating a supportive environment for the development of cooperatives ${ }^{10}$ and the ILO's Recommendation No. 193, published in 2002, concerning the promotion of cooperatives ${ }^{11}$ (Fici, 2013a). These sources of soft law all aim to

\footnotetext{
6 Economists have rarely studied cooperative membership (Jones, Jussila and Kalmi, 2016), although they have paid, in general, more attention towards cooperatives than legal scholars.

7 The concept of "core structural characteristics" is used here in the same sense in which Armour et al. (2017) use it in their famous analysis of the business corporation.

8 See similarly Henrÿ (2012).

9 See https://ica.coop/en/whats-co-op/co-operative-identity-values-principles [Accessed: August 2018].

10 See www.un.org/esa/socdev/social/documents/coop_egm_report.pdf [Accessed: August 2018].

11 See www.ilo.org/dyn/normlex/en/f.p=NORMLEXPUB:12100:0::NO::P12100_ILO_CODE:R193 [Accessed: August 2018].
} 
promote a globally shared conception of the values and principles of cooperatives; however, only the ICA Statement includes concrete information regarding cooperative membership. According to the ICA's first Cooperative Principle ("Voluntary and Open Membership"), "[c] ooperatives are voluntary organizations, open to all persons able to use their services and willing to accept the responsibilities of membership, without gender, social, racial, political, or religious discrimination".

It is stipulated in the second Principle ("Democratic Member Control") that cooperatives are democratic organizations controlled by their members, who actively participate in setting their policies and making decisions. Furthermore, according to the third Principle ("Member Economic Participation"), members contribute equitably to, and democratically control, the capital of their cooperative. Members usually receive limited compensation, if any, on capital subscribed as a condition of membership. Finally, the fourth Principle ("Autonomy and Independence") necessitates that if cooperatives enter into agreements with other organizations, including governments, or raise capital from external sources, they do so on terms that ensure democratic control by their members and maintain their cooperative autonomy. All in all, the main essence of cooperative membership is encapsulated in these principles, and they demonstrate how member-centred enterprises cooperatives are. However, the ICA Statement is quite vague and open for interpretation; therefore, in 2015, the ICA issued the so-called "Guidance Notes" to elaborate on how the Statement, which has been reviewed and reformulated several times, should be understood in the modern business environment (ICA, 2015). These notes also contain important information on cooperative membership.

As for sources of hard law, e.g., the European Cooperative Society Regulation of 2003 (SCE Regulation) contains several articles concerning cooperative membership ${ }^{12}$. Articles 14 and 15 deal with acquisition and loss of membership, Article 16 with financial entitlements of members in the event of resignation or expulsion and, furthermore, Chapters III and V of the SCE Regulation include several provisions concerning the members' governance and financial rights and obligations. National cooperative laws also regulate membership and often have a separate chapter or part for membership-specific provisions ${ }^{13}$. National laws cannot be introduced here in detail; however, they are used later as examples to show how the ICA's Cooperative Principles, in particular, have been translated into legal rules.

Finally, it is worth noting that the Principles of European Cooperative Law (PECOL 2017), published by the Study Group on European Cooperative Law in 2017, regulate cooperative membership rather comprehensively (Fajardo et al., 2017). The PECOL 2017 includes provisions on membership requirements (Section 1.3), cooperative transactions with members and non-

\footnotetext{
12 The SCE is an EU association form provided by the Council Regulation (EC) 1435/2003 on the Statute for a European Cooperative Society [2003] L 207/1. Council Directive 2003/72/EC supplementing the Statute for a European Cooperative Society with regard to the involvement of employees [2003] L 207/25 supplements this statute with rules on the involvement of employees.
}

13 Such chapter or part can be found in the cooperative acts of Canada, Finland, Sweden and the UK. 
members (Sections 1.4-5), open membership (Section 2.2), members' rights and obligations (Section 2.3), members' governance and information rights (Sections 2.4 and 6), and members' contribution to capital and limited liability (Sections 3.3 and 5). Although the PECOL 2017's objective is to provide a better understanding of cooperatives and the legal principles on which such entities rely-and although these principles are not legally binding-it is, nevertheless, an important source for scholars as well as lawmakers. Hence, the PECOL 2017 (Fajardo et al., 2017) is often cited in this article.

\subsection{General observations}

As mentioned in Section 1, the legal nature of cooperative membership is one of the core structural characteristics of the cooperative form and an element that distinguishes cooperatives from mainstream companies: cooperatives are person-centred mutual enterprises, while companies are investor-driven for-profit organizations. Cooperatives are owned and administered by their members, who are at the same time customers, providers, and/or workers of the enterprise. Hence, cooperative members undertake a transactional and an organizational relationship with the society (Fici, 2013a; 2017b), i.e., they possess a "dual role" or a "double quality" as owner-users of the firm ${ }^{14}$. Like the shareholders of a company, the members of a cooperative can be natural persons (individuals) as well legal persons, such as companies and other cooperatives (ICA, 2015; Fajardo et al., 2017). Of course, not all cooperatives accept legal persons as their members and vice versa. In some jurisdictions, legal persons are excluded from membership in primary cooperatives; however, most cooperative statutes — such as the SCE Regulation-have not introduced such restrictions (Henrÿ, 2012). If cooperatives accept legal persons as their members, national laws should ensure that they are treated equally with individual members.

In principle, cooperatives do not assign investor shares as mainstream companies do. Cooperative members, however, have to subscribe "cooperative shares", which do not determine the extent of a member's governance and financial rights; a cooperative share is merely a condition for membership, i.e., an "entrance fee" (Fici, 2013a). In fact, to make a clear distinction between them and the shares of a company, it might be appropriate to term cooperative shares "compulsory capital contributions", "member/membership shares" (Henrÿ, 2012; ICA, 2015; Fajardo et al., 2017), or "advance payments for future services" (Helm, 1968). I.e., in a cooperative context, the rights and duties of the owners are attached to an instrument called membership and vice versa

\footnotetext{
14 In practice, this dual role does not actually distinguish cooperatives from SMEs, which provide services for their owners. E.g., an electric company, whose sole purpose is to generate affordable products (electricity) for its owners, shares, in practice, many similarities with an electric (producer) cooperative. See differently Fici (2017b).
} 
in companies to something we call shares or stock ${ }^{15}$. However, to survive the competition against companies, some cooperatives have developed instruments ${ }^{16}$, which can be perceived as investor shares (Chaddad and Cook, 2004), i.e., shares that are owned by non-member parties ${ }^{17}$. Such instruments, which some scholars consider desirable (e.g., Mills, 2013), are not problematic per se as long as they do not dilute the meaning of membership (e.g., governance rights should never be attached to shares of any kind).

Then again, membership of a cooperative and membership of an association have been recognized as rather similar legal constructions, even though cooperatives are business organizations (like companies) and associations are non-profit ("ideal”) consortiums ${ }^{18}$. Cooperative membership also shares some structural similarities with partnership in a partnership and Münkner (2017: 254) is - at least to some extent - right when characterizing the cooperative society as a "hybrid form of association between partnership and company" ${ }^{19}$. After all, membership/partnership, per se, is only an expression of its holder's personal relation to a society and its legal effects (i.e., the member's/partner's rights and obligations towards the society) are derived from law and the rules of the society. In practice, this means that membership and partnership_ — as well as the share of a company_are only figurative platforms for different kinds of legally enforceable rights and obligations.

Cooperatives_-just like companies_are legal persons independent from their owners. I.e., cooperatives enjoy patrimonial autonomy meaning that they have their own assets to fulfil

15 Here it is not possible - even for the purpose of comparison - to analyze the legal nature of a company's share; however, it is worth mentioning that this problem has not been thoroughly assessed in jurisprudence. E.g., Davies (2012: 815) has remarked that the question of the legal nature of a share "is a question more easily asked than answered" and, furthermore, Ferran (1999) and Ireland (1999) have even claimed that there is no comprehensive legal definition for a share. In common law countries, the definition of a company's share is usually derived from Borland's trustee $v$ Steel Brothers \& Co $L t d$ [1901] 1 Chapter 279, 288; where the court ruled that "[a] share is the interest of a shareholder in the company measured by a sum of money, for the purpose of liability in the first place, and of interest in the second, but also consisting of a series of mutual covenants entered into by all shareholders inter se... The contract contained in the articles of association is one of the original incidents of the share. A share is not a sum of money ... but is an interest measured by a sum of money and made up of various rights contained in the contract, including the right to a sum of a more or less amount".

16 In some countries, such as Finland and Sweden, the national lawmaker has even introduced investor shares that are intentionally meant to resemble the shares of a company.

17 The PECOL 2017 includes the definition of "non-cooperator members". According to Section 1.3(3) "[n]on-cooperator members are natural or legal persons, such as investors, volunteers, or public bodies, who do not engage in cooperative transactions but are interested in pursuit of the cooperative objective" (Fajardo et al, 2017: 38). The PECOL 2017 permits cooperative transactions with such non-members, but within certain limits and upon certain conditions (see Section 1.5).

18 E.g., Swedish cooperatives are called "economic associations" (ekonomiska föreningar), not cooperatives.

19 Membership and partnership are both based on personal relations between the members/partners, and the members/ partners are themselves responsible for cooperative/partnership governance (Münkner, 2017). On the other hand, unlike cooperative members, partners of a partnership are personably liable for the undertakings of their firm. Moreover, partnerships are not "open" in the same sense as cooperatives. 
their purposes. As mentioned above, members have to take cooperative shares and these capital contributions form a financial bond between the firm and its owners. The main trend today is to limit the members' liabilities regarding the undertakings of the cooperative to these contributions (Fajardo et al., 2017); hence, limited liability is an essential element of cooperative membership ${ }^{20}$. There are, however, several countries, which have made legislative exceptions to the principle of limited liability and in France, e.g., the members' liability in certain types of cooperatives is extended to ten times the subscribed capital (Hiez, 2017). Such normative exceptions are, however, quite uncommon and the more typical method is to permit by-law autonomy regarding the financial liabilities of the members ${ }^{21}$. In Finland and Germany, e.g., it may be stipulated in the cooperative by-laws that in the event of the cooperatives' insolvency, the members are personally liable for the debts of the firm (Münkner, 2016) 22 . Furthermore, it is important to remember that cooperatives are subject to the legal doctrine known as "piercing the corporate veil", which can result in the members losing their shield against the demands of the cooperative's creditors. Although the veilpiercing dilemma has been investigated extensively by company law scholars, in a cooperative law context it has received only little academic attention.

Cooperative membership is, in principle, non-transferrable, unless otherwise provided in the by-laws ${ }^{23}$. The same rule concerns cooperative shares and in many jurisdictions share transfers have to be approved by the board of directors or another organ, such as the general meeting (Henrÿ, 2012; Fici, 2013a) ${ }^{24}$. Then again, there are countries, such as Finland, where cooperative membership is per se non-transferrable, but cooperative shares (as well as investor shares) can be transferred freely. As for involuntary transfers of cooperative shares_-such as mortis causa transfers and insolvency related seizures - the rules are different. In Europe, the common trend seems to be to allow share transfers to the members' heirs if they are already members of the cooperative and if so requested. Heirs who

\footnotetext{
20 However, this does not mean that the necessity of limited liability should be taken for granted. In cooperative law theory, the doctrine of member limited liability has been ignored, for the most part, although scholars should by nature question the justifications of such a significant privilege. It is also important to stress that due to the differences between cooperative membership and company shareholdership, the justifications for shareholders' limited liability cannot be used, as such, to explain why cooperative members should enjoy similar protection. This topic requires further research and it cannot be discussed here further.
}

21 In some jurisdictions, such as Australia, the name of the cooperative must indicate whether the enterprise is a limited liability cooperative. See Section 220(3) of the Co-operatives National Law (South Australia) Act 2013. See also Article 1(2) of the SCE Regulation: "Where the members of the SCE have limited liability, the name of the SCE shall end in 'limited'".

22 See also Art. 1(2) of the SCE Regulation: "Unless otherwise provided by the statutes of the SCE when that SCE is formed, no member shall be liable for more than the amount he/she has subscribed".

23 There are, however, some countries where the national cooperative law allows the transfer of membership. See, e.g., South Africa’s Co-operatives Act 2005 and Turkey Cooperatives Law 1163/1969.

24 See also Section 3.3(6) of the PECOL 2017, which treats transfers of member shares and non-member shares differently. 
do not want to- or are not able to- - be members of the cooperative, are only entitled to the value of the inherited shares. Accordingly, the creditors of a member cannot become cooperative members or owners of cooperative shares, but they are allowed to seize the member's reimbursements, interests, and refunds to collect their debts (Fajardo et al., 2017). Furthermore, if legal persons are allowed to be members of a cooperative, it should be decided what happens to the membership if the member, e.g., merges to another entity and consequently ceases to exist: is the membership transferred to the acquiring entity or will it be terminated?

Finally, the personal nature of cooperative membership means that no person can hold more than one membership in a cooperative. Cooperatives are democratic organizations, governed by the "one member, one vote" principle, hence, there are no valid grounds to allow anyone to possess multiple memberships. This does not concern cooperative shares and some national laws permit cooperatives to stipulate in their by-laws that members have to/may take more than one cooperative share or investor share ${ }^{25}$. Therefore, the financial rights and obligations of cooperative members may differ from one another. Furthermore, cooperative membership is indivisible, i.e., the membership—or, more precisely, the rights and obligations of a member-cannot be shared by different people. There are, of course, exceptions to this rule and, e.g., some cooperatives permit only one membership per household so that voting rights are not concentrated in larger families (Birchall, 2011). In such cases the members of the same household may be entitled to share the benefits of membership, however, these benefits cannot be shared, e.g., with members of another family.

\subsection{Voluntary and open membership}

Cooperative membership is voluntary and open to all persons able to use their services and willing to accept the responsibilities of membership. The voluntary nature of membership is not, however, a distinctive feature of the cooperative in comparison to companies, since neither membership of a cooperative nor shares of a company can be obtained without the consent of the potential member/shareholder ${ }^{26}$. Then again, voluntary membership can be understood in a broader sense to also encompass the freedom to withdraw from the society; i.e., the open-door principle applies both ways-to entrance and exit. Here cooperatives differ essentially from companies, where the

\footnotetext{
25 E.g. according to Chapter. 9, Section 1 of the Finnish Cooperatives Act 421/2013 (FCA) it can be stipulated in the cooperative's by-laws that the members may/must take additional cooperative shares and/or investor shares and that both types of shares can be given also to non-members. Furthermore, according to Chapter 9, Section 2 of the FCA cooperatives may issue - and even without the support of their by-laws—new traditional and investor shares for members as well as non-members.

26 I.e., no one can be forced to be a member of a cooperative or to accept shares in a company. However, some countries have enabled government authorities or cooperatives to require persons to become members of a cooperative under certain conditions (Münkner, 2015). Such requirements are in violation of the ICA's first Cooperative Principle (ICA, 2015) and attempts to force cooperation have usually failed.
} 
shareholder has no such freedom of exit in relation to her/his shares, which bind her/him as a shareholder to the society. In practice this means that shares of a company cannot be abandoned or otherwise renounced by their holder, i.e., the shareholder is bound to her/his shares until someone (i.e., the company or another person) either takes (purchases, inherits, redeems etc.) them or the company ceases to exist.

As cooperative membership is voluntary, cooperatives should not-in principle-be allowed to "imprison" their members, i.e., limit their freedom of exit (ICA, 2015). In addition, as Fici (2013a) pointed out, the right to withdraw from the society is an important means of reacting to the abuses of authority by the directors and other members. Hence, the right to exit can be perceived as an essential instrument of minority protection ${ }^{27}$. In practice, however, it is often in the members' own interest that there are certain limitations regarding the right to withdraw from the cooperative, since a sudden "exodus" of members might harm the enterprise as well as its business partners (Münkner, 2015). Cooperatives have several mechanisms to protect themselves from harms inflicted by member withdrawals and, e.g., resignation may be restricted for a certain period of time and members may be subject to fulfil certain (mainly financial) obligations towards the society before withdrawal (Henrÿ, 2012; Münkner, 2015; Fajardo et al., 2017). Furthermore, in some cooperatives (such as agricultural and worker cooperatives) withdrawal of capital may need to be phased over time or subject to reasonable delays (ICA, 2015) ${ }^{28}$. Nevertheless, preconditions for member withdrawals must always be based on objective and reasonable grounds and all artificial limitations to the freedom of exit should be considered illegal and unenforceable. In fact, national lawmakers should set a general threshold for withdrawal restrictions as cooperatives may be-and especially for financial interests - reluctant to admit their members' fair and realistic terms for exit ${ }^{29}$.

The main purpose of the open-door principle is to prevent the existing members from closing the cooperative from people who are able and willing to become fellow members. As Fajardo et al. (2017) have argued, cooperative members should not be allowed to profit from transactions involving non-members with the same economic relationship with the society by denying membership from them. This means that the principle of equal treatment protects both members and such non-members who are transacting with the enterprise. This is a distinctive feature of the cooperative form since for companies there is no similar requirement to allow non-shareholder parties to become owners of the enterprise, even though they would formally fulfil the requirements

\footnotetext{
27 Similarly, in companies the free transferability of shares is an essential part of the protection of minority shareholders.

28 It must also be noted that in some cooperatives (e.g., agricultural marketing cooperatives), members have separate contracts with the enterprise and it may be agreed that the resignation of a member will not terminate her/his contractual obligations towards the cooperative (Fajardo et al., 2017). Although such contractual arrangements are, in principle, legally enforceable, they should never be used to unjustly limit the members' freedom of exit.
}

29 However, in some jurisdictions, the situation seems to be just the opposite. E.g., in Italy, the law permits member withdrawal only in certain, limited situations (Fici, 2017a). 
of shareholdership (Pönkä, 2016b) ${ }^{30}$. Here one must remember that cooperatives, as opposed to companies, are entities whose benefits should be shared by the largest possible number of persons and therefore the existing members have to accept the potential reduction of their utility by sharing the overall utility with new members (Fici, 2013a).

According to the ICA's Guidance Notes (ICA, 2015), the openness of cooperative membership affirms the "fundamental dignity" of every person and their right to be part of the cooperative movement. This has been a basic commitment of all cooperatives since their emergence in the mid19 th century and even today cooperatives are recognized as open societies in virtually all modern jurisdictions. That said, it has raised some discussion as to whether cooperatives should be open to anyone who is able to use their services and willing to accept the responsibilities of membership or whether cooperatives should be open only to the extent that a cooperative is prohibited from refusing membership on, for instance, gender, social, racial, political, or religious grounds. This debate is not explained in detail here, since today there seems to be a broad consensus that the primary purpose of the open-door principle is to prevent the occurrence of artificial and unreasonable restrictions on cooperative membership (Henrÿ, 2012; ICA, 2015; Münkner, 2016; Fajardo et al., 2017), or as Fici (2013a: 56) puts it, "to ensure that a cooperative does not become a sort of closed club where benefits are shared only among current members". Hence, cooperatives are not as open societies as the wording of the ICA's first Cooperative Principle suggests.

In practice, the purpose of the cooperative is the primary limiting factor for open membership $($ ICA, 2015) 31 . This means that the extent of the openness of membership is not fixed, but it varies between different types of cooperatives. E.g., membership of a consumer cooperative should be open to all customers (Gide, 1922) while all employees in a workers' cooperative must have an equal right to become co-members (Fajardo et al., 2017) ${ }^{32}$. Several national laws, however, allow cooperatives to determine in their by-laws specific qualifications for their members. This means that lawmakers must decide which kinds of membership criteria are acceptable, and which are not ${ }^{33}$. It is, of course,

30 Fici (2013a) is quite right when arguing that companies are not open in the same sense as cooperatives and the circulation of company shares only results in variation of the owners' identity but not in the total number of owners.

31 As for personal qualifications, age has sometimes been recognized as another general limiting factor for cooperative membership (Henrÿ, 2012). However, there are also laws, which explicitly permit membership for people under the age of 18. E.g., according to Section 31(1) of the UK's Co-operative and Community Benefit Societies Act 2014 "[a] person under the age of 18 may be a member of a registered society unless the society's registered rules provide otherwise".

32 In some countries, however, employees have no such right to become members of a workers' cooperative. E.g., in France workers' cooperatives do not even have to give the applicant an explanation for the rejection of her/his application. The rejected employee can only renew her/his application each year (Hiez, 2017). On the other hand, such consumer cooperatives, which offer necessities (such as groceries or banking services), can hardly ever find reasonable grounds to reject membership applications (Olsson, 1982; Pönkä, 2016a).

33 There are also laws (such as certain French cooperative laws), which explicitly define the possible members, and applicants who do not meet these requirements cannot be admitted membership of that cooperative (Hiez, 2017). 
necessary to require that cooperatives do not discriminate member candidates, i.e., that they do not reject membership applications without objective and reasonable grounds. However, within this general precondition, cooperatives should have a somewhat wide discretion regarding who is able to use their services and carry the responsibilities of membership. As cooperative members possess a dual role as owner-users of the enterprise, in certain situations cooperatives must build up a relatively homogenous body of members. For example, in profession-based cooperatives, only those persons can become members who belong to that particular profession, and in housing cooperatives new members can be admitted only if old members resign and the new candidates meet certain financial requirements (Münkner, 2016). Overall, there has to be a reasonable balance between the interests of the existing members and the people applying for membership.

Another vital question which national lawmakers shall decide regarding member selections is how to treat cooperatives which discriminate applicants or which do not follow their own admissions criteria. In cooperative law theory, there seems to be a somewhat wide consensus that no-one has a subjective (i.e., legally enforceable) right to join a cooperative (Fici, 2013a; Münkner, 2015; Fajardo et al., 2017) and in some jurisdictions, such as Finland, scholars unanimously agree that courts cannot obligate cooperatives to take new members, even those who fulfil all the preconditions for membership (Olsson, 1982; Pöyhönen, 2011; Pönkä 2016a). In such jurisdictions, it is highly important that the law provides the discriminated person the right to challenge the cooperative's decision for sufficient compensation. In addition, the admissions proceeding must be regulated carefully to ensure that all applications are decided in an equal and timely manner. For example, according to Section 2.2(2) of the PECOL 2017, cooperative statutes must ensure that "(a) membership applications are dealt with by a designated organ within a reasonable time; (b) reasons are given for refusal; (c) the applicant can appeal to the members' meeting if a different organ refused admission; and (d) the applicant has the right to be heard before a decision is made on the appeal" (Fajardo et al., 2017: 49-50). As mentioned, national laws should also provide the rejected person reasonable access to justice.

Finally, member expulsions are, unfortunately, quite common, although in light of the opendoor principle, some cooperative law scholars believe that such exclusions should be treated as exceptional measures (Henrÿ, 2012) 34 $^{34}$ In principle, a cooperative must have the right to expel a member conferred either by law or the cooperative's by-laws (Fajardo et al., 2017) butsurprisingly_several cooperative laws (as well as the PECOL 2017) include no default rules regarding the grounds for exclusion. On the other hand, in jurisdictions where such default rules exist, cooperatives nevertheless have to tailor them since one model hardly ever fits all. In addition, default rules regarding the grounds for exclusion are often too vague and open for interpretation, hence in most circumstances the organ, which makes the decision on exclusion, needs more precise

\footnotetext{
34 In practice, disputes between cooperatives and their members are often related to exclusions, or at least they result in a member being excluded from the society. There is, however, hardly any research regarding conflicts within cooperatives and scholarly work on the topic would be highly valuable de lege ferenda.
} 
guidelines to determine whether a member should be expelled or not ${ }^{35}$. Then again, member exclusions always require through, case-by-case consideration and a general threshold for exclusions cannot be comprehensively adjusted in the by-laws. For the expelled member, this means that the decision-makers cannot simply hide behind the cooperative by-laws but instead must personally face the consequences of wrongful decisions.

\section{Members' rights and obligations}

\subsection{General considerations}

There are several ways to systematize the different rights and obligations related to cooperative membership. Münkner (2016), for example, has distinguished personal rights and obligations from financial ones. However, sometimes it can be quite difficult to determine which rights and obligations are-directly or indirectly_financial in nature and which ones are not. Henrÿ (2012) has used a similar categorization and, in addition, he perceives "moral obligations" distinct from personal and financial ones. Henrÿ argues that the duty to work with the cooperative can be difficult to translate into a legal obligation (such obligation might, e.g., violate competition laws) and therefore there is a need to differentiate legally enforceable duties from those which are not. Furthermore, Section 2.3 of the PECOL 2017 outlines some of the members' obligations and rights and also recognizes "investor members" and "non-cooperator members" as independent interest groups ${ }^{36}$. The PECOL 2017 does not utilize the distinction between personal and financial rights/obligations, however, individual rights are distinguished from collective rights, i.e., rights which can be exercised only by a certain group of members (e.g., a group consisting of 10 percent of all members).

There is little point in trying to list all the different rights and obligations related to membership, however, some general considerations are necessary to demonstrate how cooperative membership differs from company shareholdership. Such considerations also show how the ICA's Cooperative

\footnotetext{
35 E.g., according to Article 15(1) of the SCE Regulation membership shall be terminated "if the member commits a serious breach of his/her obligations or acts contrary to the interests of the SCE." Such provision gives the cooperative too much discretion regarding the grounds for exclusion and provokes unnecessary disputes between the expelled member and the cooperative. On the other hand, grounds for exclusion must be general to some extent, since too casuistic rules often contain unintended loopholes.

36 Cooperative law scholars often start by introducing the members' rights and then move on to their obligations while the PECOL 2017 first recognizes the duties of the cooperator members. The decision regarding what comes first—rights or obligations - is not only a matter of presentation technique, as emphasis on the members' obligations demonstrates that cooperatives place "us" not "me" to the center or—or as Henrÿ (2017: 47)—puts it, "the co-operative does not do anything for its members. The members do together something for themselves by means of the co-operative enterprise".
} 
Principles translate into legally enforceable rules ${ }^{37}$. In the following Sections 3.2 and 3.3, the members' rights and obligations are briefly introduced by dividing them into governance and financial rights and obligations. As implied above, this is not the conventional approach, but one often used when investigating the rights and obligations of a company's shareholder (Ferran, 1999). It is important to note that no systematization is unambiguously better than another and that all of them have only pedagogical (i.e., descriptive) value.

Furthermore, it must be kept in mind that cooperative members have certain "fundamental" rights and obligations, which cannot be constrained into any specific category. For instance, the right for equal treatment (mentioned above in Section 2.2) and the obligation to be loyal towards the society (Münkner, 2016) are guiding principles concerning all interactions between the members and the cooperative society. Also, the right and duty to interact with the cooperative cannot be perceived as a governance or financial right/obligation. It is neither a personal right as cooperatives often transact with non-members. Here participation in cooperative transactions is understood as a member's fundamental right/obligation since cooperatives are service organizations and, as Fici puts it, such participation is one of the most significant elements of cooperative identity (Fici, 2013b): if members were not to transact with the society, it could not be identified as a cooperative ${ }^{38}$.

\subsection{Governance rights and obligations}

The governance rights and obligations related to cooperative membership are encompassed in the ICA's second Cooperative Principle: cooperatives are "democratic organizations controlled by their members, who actively participate in setting their policies and making decisions”. This means that the members have both a right and a duty to take part in cooperative governance, although it may be quite difficult to legally obligate them to participate in the administration of the enterprise (Henrÿ, 2012). In practice, such requirement may take the form of minimum attendance at the general meetings (Fajardo et al., 2017) and in some jurisdictions non-attendance may even lead to expulsion (Münkner, 2016). Since virtually all national cooperative laws permit —or even require-a delegated management with a board structure (Cooperatives Europe, 2016; Armour et al., 2017), the duty to take part in cooperative governance is usually limited to attendance at the general meetings,

\footnotetext{
37 Also, e.g., Section 2.3 of the PECOL 2017 deals exclusively with those obligations and rights which are linked to the ICA Statement.

38 On the other hand, Fici (2013b) is quite right when arguing that the members' right and duty to transact with the cooperative is not only a significant, but also a controversial element of cooperative identity. As mentioned, the duty to take part in cooperative transactions is difficult to translate into a legal obligation and such requirement is usually found only in statutes concerning particular types of cooperatives (Fajardo et al., 2017). On the other hand, the question, should cooperatives be allowed to transact with non-members, has raised much debate among scholars (Fici, 2013a; 2013b). Furthermore, the right/duty to transact with the cooperative is related to the general problemacy regarding asset distribution as, i.e., should cooperatives be allowed to distribute their assets to the members in form of monetary reimbursements that are unrelated to the services offered by the society (see Section 3.3).
} 
hence other administrative duties are delegated to volunteers or hired professionals. In international cooperative law research there is, however, some debate on whether some or all board members should be members of the cooperative or representatives of its different interest groups (Fici, 2013a; 2013b). Without going further into this problematic, it can be noted that if members are included in the composition of the board, they must have an obligation to stand as candidates in board elections.

Member control refers to the members themselves having the ultimate authority over all important matters concerning the cooperative enterprise. Such matters include board elections, amendments to the by-laws, mergers and demergers as well as dissolution. According to the ICA's Guidance Notes (2015) the distinction between important matters decided by the members and other matters delegated to the board is for each cooperative to decide, however, there are certain issues, such as the members' rights and duties and dissolution of the society, which should never be decided by the board. Furthermore, the democratic nature of the cooperative society refers to the principle of majority rule being applied in all decision-making situations (Gide, 1922), hence the members are obliged to respect the will of the majority as long as it has not acted against the law, or the cooperative's by-laws, or otherwise abused its authority.

The basic rules of governance described above are not, as such, distinctive features of the cooperative form. However, the division of powers among the members distinguishes cooperatives from companies (Pönkä, 2017). As declared in the ICA's second Cooperative Principle "[i]n primary cooperatives members have equal voting rights (one member, one vote)", which means-as opposed to companies - that personal participation of each individual member is considered more important than financial contributions (Münkner, 2015). Hence, the right for one vote-and for one vote only - is a fundamental governance right and, in theory, cooperatives can be perceived as "miniature republics" where equality among members is ensured by the "one man one vote" maxim (Gide, 1922). Then again, in most jurisdictions cooperative laws permit deviations from this democratic rule and, e.g., in the US, many states have allowed a system where every member has at least one vote at the general meeting and extra votes are added in proportion to a member's equity or volume of patronage (Reynolds, 2000) ${ }^{39}$. Furthermore, according to Article 59(2) of the SCE Regulation, a cooperative's by-laws may "provide for a member to have a number of votes determined by his/her participation in the cooperative activity other than by way of capital contribution". The justifications of proportional voting cannot be discussed here further, however, it is necessary to stress that voting rights should never be determined by capital contributions. Otherwise cooperatives may transform into investor-driven companies, which place capital, not people, in the centre.

As mentioned, the primary governance rights related to cooperative membership are: (i) the right to participate in the administration of the society; and (ii) the so-called rule of "one member,

\footnotetext{
39 Reynolds has also thoroughly analyzed the positive and negative effects of the rule of proportional voting. In brief, his analysis shows that although some cooperative theorists object to the idea of proportional voting, all seem to agree that cooperatives should have the freedom to decide whether or not to deviate from the one member, one vote principle.
} 
one vote". There are also several other (supplementary) governance rights whose main function is to support and enhance the primary rights. First, it is not enough that the members have the right to attend general meetings and vote there, but they must also have the possibility to ask questions, set motions, use legal assistants and, in case of absence, exercise their rights by proxy. Second, cooperative members must have sufficient access to information concerning the decisions and undertakings of the society. On the one hand, this enables the members as decision-makers and, on the other, allows the "minority" members to supervise the "majority" members and the directors ${ }^{40}$. In practice, information rights can be either passive or active meaning that information may be provided automatically (e.g., in the form of annual reports) or require a certain level of activity (e.g., request for an additional audit). Third, information rights must be supplemented by efficient sanctions against detected abuses of authority. Such sanctions include at least the right to: (i) object to decisions; (ii) claim for damages; and (iii) exit the society. Finally, as the ICA's fifth Cooperative Principle suggests, cooperative members must have access to education and training "so they can contribute effectively to the development of their cooperatives". In most countries the question of education and training of members and directors has not, however, been regulated at all (Münkner, 2015) $)^{41}$.

Comparative studies, such as the International Handbook of Cooperative Law (Cracogna, Fici and Henrÿ, 2013), indicate that there are several ways in which the above-mentioned governance rights and obligations can be regulated. Nevertheless, legal rules on cooperative governance should always support the mutual purpose of the cooperative enterprise by enabling the members as equal and well-informed decision-makers with sufficient access to justice. Cooperative governance and corporate governance share many similarities and there is no reason why the governance structures of these two business forms should differ from one-another. In fact, studies on corporate governance can be used to develop cooperative governance as long as cooperative identity is safeguarded and the meaning of membership is not diluted by overemphasizing (law and economics inspired) values such as efficiency, growth, and competitiveness. Furthermore, national laws should provide some flexibility regarding members' governance rights and obligations since cooperatives are heterogeneous and one set of rules hardly ever fits all (Münkner, 2016). Even the rule of one member one vote should not be perceived exceptionless, as the rule seems to work inefficiently in cooperatives where the members do not form a homogenous interest group; or as Holmström (1999) puts it, in such cooperatives the potential value of the vote is often lost in member quarrels

\footnotetext{
40 Although commonly used by cooperative law scholars, the terms "minority members" and "majority members" are somewhat misleading as all cooperative members have usually only one vote at the general meeting. Precisely speaking, in cooperative context, the concept of majority refers to a group of controlling members using their decision-making powers together. Other members are accordingly understood as minority members.

41 See differently Section 2.3(1) of the PECOL 2017, which requires that the cooperator members participate in education and training. From a legal perspective this requirement is somewhat problematic as it is most probably unenforceable. Also, some members might consider mandatory training rather contrived.
} 
and indecisiveness. Furthermore, innovations, such as proportional voting, can even support the dual nature of cooperative membership by inducing the members to engage into transactions with the cooperative enterprise (Fici, 2013a).

\subsection{Financial rights and obligations}

Since cooperatives are service organizations, financial rights do not play_or at least they should not play - a particularly significant role for the members. As mentioned above in Section 3.1, the right to participate in cooperative transactions does not translate into a financial right, even though such participation often promotes the members' economic interests (Münkner, 2016). Financial rights are rather rights which have direct monetary value. They include the right to receive: (i) compensation (i.e., interest) for subscribed capital and a share of the cooperative surplus; (ii) a share of the funds of a dissolved cooperative; and (iii) reimbursement of paid-up shares upon exit (Henrÿ, 2012). Limited liability can also be perceived as a financial right as it provides a shield for the members against the claims of the cooperative's creditors (see Section 2.2). In practice, the financial rights can be understood as follows:

1. According to the ICA's second Cooperative Principle, members may receive limited compensation, if any, on subscribed capital, i.e., shares ${ }^{42}$. Cooperative surplus may also be used to pay a return to the members in the form of dividends, patronage refunds, or bonuses (ICA, 2015). Therefore, cooperatives, as well as national lawmakers, must decide to what extent economic benefits may be channelled to the members as monetary reimbursements, which are not related to the actual services offered by the enterprise ${ }^{43}$. Furthermore, it must be determined whether cooperative surplus is distributed to the members in the form of fixed interest or dividends. Fici (2013a) has argued that if the possibility to pay returns is recognized by law, the payment of fixed interest should be prioritized as cooperatives are not seeking to maximize profits, but to service their members. However, Münkner (2015) is also correct when noting that a fixed rate of interest cannot be guaranteed because of the uncertainty of making surplus in the future. Therefore, he suggests that cooperative surplus should be distributed as dividends or, more precisely, as patronage refunds ${ }^{44}$. More important is that cooperative statutes should never empower cooperatives to pay returns without any limitations because such restrictions protect cooperative identity and prevent so-called "dividend hunting" (Surridge and Digby, 1967).

\footnotetext{
42 However, initially the Rochdale Society's rules required that "capital should bear a fix rate of interest".

43 This question is too broad to discuss here in detail; however, it must be noted that cooperatives should pursue to service their members at near cost price to fulfil their purpose as service organizations (Münkner, 2015). Therefore, cooperatives should never prioritize monetary reimbursements and some have even argued that in order to show that a cooperative has acted effectively in favor of its members, it should not generate any divisible profits (Fici, 2013a).

44 Here patronage refund is understood simply as dividend which is paid to the members ("patrons") based on quantity or value of business done with the cooperative (Frederick and Ingalsbe, 1985), i.e., not in proportion to invested equity.
} 
Finally, cooperatives and national lawmakers have to decide how returns are divided between the members. Although national laws often allow cooperatives to decide this matter themselves, the common default rule seems to be that returns are paid in proportion to the quantity and/ or quality of participation in cooperative transactions. Such a model is also introduced in the PECOL 2017.

2. The right to receive a share of the funds of a dissolved cooperative means that in case of liquidation, the residual net assets are distributed to the members. The same model is utilized in company context; however, many national cooperative laws have, at least to some extent, departed from member primacy doctrine (Fici, 2013a). In France and Spain, for example, the net assets of a dissolved cooperative must be assigned to another cooperative or a social enterprise, and in Italy to a federation of cooperatives (Fajardo et al., 2017). Then again, there are countries like Finland, Germany, and Sweden, where the members have the right to the dissolved cooperative's net assets unless otherwise provided in the bylaws. In cooperative law theory, there appears to be hardly any debate regarding this problem and, e.g., Fici (2013a) has argued that a system where the assets are distributed to the members in proportion to their individual participation in cooperative transactions (member-centred model) is as compatible with the nature of the cooperative as a system where the assets are used to promote the cooperative movement, sustainable development, or social values in general (altruistic model): the choice of the addressee only reflects the values of the lawmaker ${ }^{45}$.

3. As explained above in Section 2.3, the right to exit the cooperative is a vital element of the opendoor principle. If a member decides to leave the society (or is excluded from it) he/she may, according to most cooperative statutes, require reimbursement of paid-up shares (Fajardo et al., 2017). As opposed to companies, this right concerns only the nominal value (not true value) of the shares in order to avoid membership motivated speculation (Henrÿ, 2012). It is also important to remember that the right for reimbursement upon exit does not necessarily mean that the member has to be reimbursed immediately, but the payment may be delayed for a fixed period of time (see Section 2.3). Moreover, as expressed in Section 3.3(7) of the PECOL, capital contributions may not be totally redeemed since the contribution must be first liquidated, deducting any losses accountable to the member and any other amounts owed by the member to the cooperative. Despite these reservations, the right to require reimbursement upon exit is highly important since it ensures that cooperatives remain open both ways-i.e., entrance and exit - and that cooperation is based on genuine commitment, not on the fear of losing money ${ }^{46}$.

\footnotetext{
45 One aspect, which should be considered when deciding to whom the net assets of a dissolved cooperative are distributed, is that, if the law requires the funds to be assigned to non-members, entrepreneurs might feel reluctant to choose the cooperative as their business form.

46. It must also be noted that the right for reimbursement upon exit implies that the legal nature of the share capital of a cooperative differs from the share capital of a company, hence, one can argue that especially in cooperatives where the members are paid a fixed interest for their capital contributions share capital should be treated as debt, not as equity (Fici, 2013a).
} 
The most important financial obligation related to cooperative membership is the obligation to make financial contributions (i.e., take shares) and payments which are provided under the by-laws of the society. Münkner (2016) has argued that with the payment of the share capital contribution upon entrance, the member has met all her/his financial obligations towards the society and is entitled to make use of all advantages of membership. This remark applies to most cooperatives, however members may be obliged afterwards to take more shares and/or to make supplementary payments.

Most cooperatives require that the shares are paid "out-of-pocket" at the time the member joins the society, however, if the cost is significant, cooperatives tend to allow the payment to be phased over time (Lund, 2013). The question of whether the capital contribution is regarded as a condition for membership or a consequence of acquisition of membership is legally irrelevant — it is merely a "chicken-and-egg" dilemma (Pönkä, 2017). Some have argued, however, that contribution to capital should not be understood as a condition for membership (Fajardo et al., 2017) ${ }^{47}$. Nevertheless, if the member does not fulfil her/his financial obligations towards the cooperative, he/she may be denied of membership or expelled from the society. The cooperative may also sue a member for unpaid contributions, however, no one should be forced to become/remain a member of a cooperative as this does not facilitate healthy cooperation and in any event the member has the freedom to leave the society and be reimbursed for paid-up contributions upon exit.

As mentioned, besides the requirement to take shares, members may have supplementary financial obligations towards the society. It may be stipulated in the cooperative's by-laws that members may/have to take additional shares or otherwise support the creditworthiness of the enterprise (Henrÿ, 2012). The amount of these financial obligations has to be stated clearly in the by-laws and they may be increased only by unanimous vote of all members concerned (Münkner, 2016) ${ }^{48}$. Within these general conditions, the members' financial obligations do not have to be the same for everyone and some national laws, as well as Section 3.3(3) of the PECOL 2017, explicitly allow cooperatives to require that new members contribute with more capital due to the increased

\footnotetext{
47 Then again, the decision of whether the capital contribution is regarded as a condition for membership or a consequence of acquisition of membership might determine the starting moment of membership. In the first case, member-status is gained only after full payment of membership shares, unless otherwise provided in the by-laws. However, if the requirement to contribute capital is understood as a consequence of acquisition of membership, member-status is gained, in principle, when the membership application has been approved. Of course, this does not automatically mean that the member is entitled to utilize the services offered by the cooperative. Hence, it may—and should—be required that membership benefits are accessible only after the fulfilment of financial obligations.

48 Another option is to allow the members to decide the matter by majority or supermajority vote and give the outvoted minority an extraordinary right to exit the society. Such system is in use in, e.g., Germany (Münkner, 2016). Furthermore, the same decision-making rules must apply when financial obligations are decreased and this reduction does not concern equally all members.
} 
value of membership (Fajardo et al., 2017) ${ }^{49}$. Financial obligations may also be related to the amount of cooperative transactions, which promotes relative equality (Münkner, 2016), but which might simultaneously discourage the members to utilize the services of the enterprise. Furthermore, there may be different classes of membership so that each class has different financial obligations towards the cooperative. All in all, cooperatives must be allowed themselves to decide how their activities are financed as long as these decisions do not contradict the purpose of the cooperative and facilitate unequal treatment of the members.

Finally, it must be noted that the members may have contract-based financial obligations towards the cooperative. Such obligations are not discussed here since they are not cooperativespecific. Also, as implied above in Section 3.2, the cooperative members may be subject to the veilpiercing doctrine, but there is yet no information (e.g., case law) available regarding this possibility.

\section{Concluding remarks: cooperative membership de lege ferenda}

The cooperative business model is based on member participation and democracy. On the one hand, members own, finance, and administer the cooperative together (organizational relationship) and, on the other, they engage into transactions with the society as consumers, providers, and/or workers (transactional relationship). This dual role of the members means that the ICA's Cooperative Principles are focused primarily on membership, and when translating these principles into legal rules, special attention should be paid to cooperative identity. If membership is not regulated in the spirit of the ICA Statement, cooperatives might end up losing their soul and, in worst case, transform into capitalistic companies or even cease to exist. Therefore, all rules regarding membership should aim to promote the cooperative as a member-centred, democratic service organization distinct from other business forms, especially companies.

Since the ICA's Cooperative Principles are general and open for interpretation, national laws on membership tend to be heterogeneous. Then again, in most jurisdictions, certain fundamental membership-specific principles are recognized and preserved through law in a rather similar fashion. These principles include the open-door principle, the rule of one member one vote and the principle of equality. Comparative studies also indicate that national lawmakers have quite successfully distinguished membership from shareholdership, which is highly important as cooperatives are member, not shareholder- (i.e., investor-) centred organizations. In most cooperative laws, governance rights are attached exclusively to membership, not to the shares issued by the society. Also, it cannot

\footnotetext{
49 It is, of course, also possible that the cooperative accepts new members without the need for additional funding. Even then, the new members must be subject to a minimum capital contribution to ensure that they are genuinely committed to the cooperation. However, some cooperatives, especially large consumer cooperatives, sometimes try to expand their membership base by offering membership with huge discounts. Such growth attempts are not desirable as they do not promote genuine member commitment and may also be subject to unexpected taxes.
} 
be emphasized enough that legally cooperative shares and company shares are not similar instruments.

As for the future development of cooperative law, it is difficult to propose concrete improvements without going into casuistic. Some general observations can, however, be made. First, legal scholars seem to agree that many areas of cooperative law are yet under-researched and this concerns also several membership-related topics. Some of these under-researched topics have been briefly introduced in this article and they include the members' limited liability and the veil-piercing doctrine, asset distribution, and the question of how cooperatives should gather funding, transactions with nonmembers, the delicate balance of powers between the majority and minority members, and to what extent should "member preference heterogeneity" (Iliopoulos and Valentinov, 2018) be recognized in legislation. Only through comprehensive and profound studies it is possible to assess the need to develop the legal doctrine on cooperative membership.

Second, to determine the need to develop cooperative law, one should study cooperative-related disputes. Especially disputes in member-member and member-cooperative relations give us vital information on what works and what needs to be improved. Unfortunately, case law is often hard to access and requires international scholarly collaboration. Also, in some jurisdictions cooperative related disputes are resolved outside the courts and, e.g., arbitral awards are normally non-accessible to researchers.

Third, the future development of cooperative law depends on the values which international organizations and national lawmakers choose to promote. Münkner (2016) has presented three "strategies" for reforming cooperative legislation and, in brief, they are: (i) the membership-centred strategy; (ii) the efficiency-centred strategy; and (iii) the stakeholder-centred strategy. If cooperative law is developed utilizing the efficiency-centred strategy, as has been done in some countries (Pönkä, 2017), there is a risk that objectives such as growth, profit maximization, and market dominance may ultimately dilute the meaning of membership. In fact, the same applies to the stakeholder-centred (i.e., altruistic) strategy and even though cooperatives must carry concern for the community, they are not to be confused with non-profit organizations. All in all, only the first strategy supports genuinely the objectives of the international cooperative movement (Münkner, 2016), however, it seems that the third strategy is strengthening its foothold in cooperative (law) theory (Harrison, 2013; Henrÿ, 2013; Argyrou and Lambooy, 2017). I.e., the recent developments of the doctrine of Corporate Social Responsibility are influencing, not only the discussion regarding the purpose of the company, but also the debate on whose interests should cooperatives promote, i.e., how much emphasis should be placed on the seventh Cooperative Principle ("Concern for Community").

Finally, lawmakers should pay close attention to the fact that cooperatives are very heterogeneous, ranging from local producer cooperatives consisting of only a few members, to large multinational and multipurpose cooperatives with millions of members and turnovers counted in billions. In order to fulfil the needs of different types and sizes of cooperatives, rules on membership should be flexible, i.e. non-mandatory. This means that national lawmakers should prioritize default rules allowing cooperatives to decide membership-related matters by themselves and only rules which are necessary for preserving cooperative identity should be mandatory. Furthermore, national laws 
could offer a different set of rules for members of small and large cooperatives, however, drawing a clear distinction between "small" and "large" cooperatives can be difficult and most probably there are better ways to regulate cooperatives than to pass separate laws for different sizes of firms ${ }^{50}$.

Although the findings of this article suggest that scholars should pay more attention to the normative dimensions of cooperative membership, it does not mean that this area of law has been completely ignored. As mentioned above in Section 2.1, the PECOL 2017, and especially its commentary (Fajardo et al., 2017), includes important information on cooperative membership and national lawmakers should study it carefully when considering the need to develop the law. The PECOL 2017 is also an important source of inspiration for researchers as it opens several membership-related questions for debate.

\section{References}

Argyrou, A. \& Lambooy, T. (2017). An introduction to tailor-made legislation for social enterprises in Europe: A comparison of legal regimes in Belgium, Greece and the UK, International and Comparative Corporate Law Journal, 12(3): 47-105.

Armour, J., Hansmann, H., Kraakman, R. \& Pargendler, M. (2017). What is Corporate Law? In: R. Kraakman et al. (Eds.), The Anatomy of Corporate Law. A Comparative and Functional Approach, pp. 1-28, 3rd edition. Oxford: Oxford University Press. DOI: https://doi.org/10.1093/acprof:oso/9780198739630.003.0001

Birchall, J. (2011). People Centered Businesses. Co-operatives, Mutuals and the Idea of Membership. Houndmills: Palgrave Macmillan. DOI: https://doi.org/10.1057/9780230295292

Chaddad, F.R. \& Cook, M.L. (2004). Understanding New Cooperative Models: As Ownership-Control Rights Typology, Review of Agricultural Economics, 26(3): 348-360. DOI: https://doi.org/10.1111/j.1467-9353.2004.00184.x

Cooperatives Europe (2016). The power of Cooperation. Cooperatives Europe Key Figures 2015. Brussels: Cooperatives Europe. Authors: C. Quintana Cocolina et al. Available at: https://coopseurope.coop/resources/projects/powercooperation-cooperatives-europe-key-figures-2015 [Accessed: August 2018].

Cracogna, D., Fici, A. \& Henrÿ, H. (Eds.) (2013). International Handbook of Cooperative Law. Springer-Verlag Berlin Heidelberg. DOI: https://doi.org/10.1007/978-3-642-30129-2

Davies, P.L. (2012). Gower and Davies' Principles of Modern Company Law, 9th edition. London: Sweet \& Maxwell.

Fajardo, G., Fici, A., Henrÿ, H., Hiez, D., Meira, D., Münkner, H-H. \& Snaith, I. (2017). Principles of European Cooperative Law. Principles, Commentaries and National Reports. Cambridge: Intersentia. DOI: https://doi. org/10.1017/9781780686073

Ferran, E. (1999). Company Law and Corporate Finance. New York: Oxford University Press.

Fici, A. (2013a). An Introduction to Cooperative Law. In: D. Carcogna, A. Fici \& H. Henrÿ (Eds.), International Handbook of Cooperative Law. Heidelberg: Springer, pp. 3-62. DOI: https://doi.org/10.1007/978-3-642-301292_1

Fici, A. (2013b). Cooperative Identity and the Law, European Business Law Review, 24(1): 38-39.

50 E.g. the "French model" has been utilized, to some extent, in several jurisdictions. In this model, there are separate laws for different types of cooperatives (Seeberger, 2014). 
Fici, A. (2017a). Italy. In: G. Fajardo, et al. (Eds.), Principles of European Cooperative Law. Principles, Commentaries and National Reports. Cambridge: Intersentia, pp. 347-408. DOI: https://doi.org/10.1017/9781780686073.011

Fici, A. (2017b). The Essential Role of Co-operative Law. In: J. Michie, J.R. Blasi \&C. Borzaga (Eds.), The Oxford Handbook of Mutual, Co-operative and Co-owned Business. New York: Oxford University Press, pp. 539-549.

Frederick, D.A. \& Ingalsbe, G. (1985). What are Patronage Refunds? Agricultural Cooperative Service Cooperative: Information Report Number 9. United States Department of Agriculture.

Gide, C. (1922). Consumers' Co-operative Societies [translated from the French by the staff of the Co-operative Reference Library, Dublin]. New York: Alfred A. Knopf.

Hansmann, H. (1996). The Ownership of Enterprise. Cambridge, Massachusetts; London, England: The Belknap Press of Harvard University Press.

Hansmann, H. (2013). All Firms are Cooperatives - and so are Governments, Journal of Entrepreneurial and Organizational Diversity, 2(2): 1-10. DOI: http://dx.doi.org/10.5947/jeod.2013.007

Harrison, R. (2013). People Over Capital: The Co-operative Alternative to Capitalism. Oxford: New Internationalist Publications.

Helm, F.C. (1968). The Economics of Co-operative Enterprise. London: University of London Press.

Henrÿ, H. (2012). Guidelines for Cooperative Legislation, 3rd edition revised. Geneva: ILO.

Henrÿ, H. (2013). Sustainable Development and Cooperative Law: Corporate Social Responsibility or Cooperative Social Responsibility?, International and Comparative Corporate Law Journal, 10(3): 58-75.

Henry, H. (2017). Co-operative Principles and Co-operative Law Across the Globe. In: J. Michie, J.R. Blasi \& C. Borzaga (Eds.), The Oxford Handbook of Mutual, Co-operative and Co-owned Business. New York: Oxford University Press, pp. 39-52.

Hiez, D. (2017). France. In: G. Fajardo et al. (Eds), Principles of European Cooperative Law. Principles, Commentaries and National Reports. Cambridge: Intersentia, pp. 163-251. DOI: https://doi.org/10.1017/9781780686073.009

Holmström, B. (1999). Osuuskuntien tulevaisuus yritysmaailman murroksen valossa [The Future of Co-operatives in the Changing Business World], Kansantaloudellinen aikakauskirja, 3: 496-507.

ICA (2015). Guidance Notes to the Co-operative Principles. Available at: www.ica-ap.coop/sites/ica-ap.coop/files/ Guidance\%20Notes\%20EN.pdf [Accessed: August 2018].

Iliopoulos, C. \& Valentinov, V. (2018). Member Heterogeneity in Agricultural Cooperatives: A Systems-Theoretic Perspective, MDPI: Sustainability, 10(4). DOI: https://doi.org/10.3390/su10041271

Ireland, P. (1999). Company Law and the Myth of Shareholder Ownership, The Modern Law Review, 62(1): 32-57. DOI: https://doi.org/10.1111/1468-2230.00190

Jones, D.C., Jussila, I. \& Kalmi, P. (2016). The Determinants of Membership in Cooperative Banks: Common Bond versus Private Gain, Annals of Public and Cooperative Economics, 87: 411-432. DOI: https://doi.org/10.1111/ apce. 12135

Lund, M. (2013). Cooperative Equity and Ownership: An Introduction. University of Wisconsin Center for Cooperatives. Available at: http://www.uwcc.wisc.edu/pdf/Cooperative\%20Equity\%20and\%20Ownership.pdf [Accessed: August 2018].

Mills, C. (2013). Past, present and future. In: R. Harrison (Ed.), People over Capital. The Co-operative Alternative to Capitalism. Oxford: New Internationalist Publications.

Münkner, H-H. (2015). Co-operative Principles and Co-operative Law, 2nd edition. Zürich: Lit Verlag.

Münkner, H-H. (2016). Ten Lectures on Co-operative Law, 2nd edition. Zürich: Lit Verlag.

Münkner, H-H. (2017). Germany. In: G. Fajardo etal.(Eds.), Principles ofEuropean Cooperative Law. Principles, Commentaries and National Reports. Cambridge: Intersentia, pp. 253-345. DOI: https://doi.org/10.1017/9781780686073.010 
Olsson, C. (1982). Osuuskuntaoikeus [Cooperative Law], 3rd edition. Helsinki: Suomen Lakimiesliiton kustannus.

Reynolds, B.J. (2000). The One Member-One Vote Rule in Cooperatives, Journal of Cooperatives, 15: 47-62.

Pönkä, V. (2016a). Osuuskunnan jäsenen erottamisesta [The Exclusion of a Member of a Cooperative], Lakimies, 5: 667-690.

Pönkä, V. (2016b). The principle of equality of shares and shareholders, Nordisk Tidsskrift for Selskabsret, 1: 38-49.

Pönkä, V. (2017). Are Cooperative Societies Transforming into Cooperative Companies? Reflections on the Finnish Cooperatives Act. Available at SSRN: https://ssrn.com/abstract=3072280 [Accessed: August 2018]. Forthcoming in (2019) European Business Law Review, 30(1).

Pöyhönen, S. (2011). Omistajaoikeudet ja omistaja-arvo osuuskunnissa [Ownership rights and owner value in cooperatives]. Hämeenlinna: Talentum.

Seeberger, L. (2014). History of the evolution of cooperative law from its origins to the present day, Revue internationale de l'économie sociale, 333: 63-79.

Siems, M.M. (2008). Convergence in Shareholder Law. Cambridge: Cambridge University Press.

Surridge, B.J. \& Digby, M. (1967). A Manual of Co-operative Law and Practice, 3rd edition. Cambridge: Heffer \& Sons.

Wolff, H. (1907). Co-operative Banking: Its Principles and Practice. London: PS King. 